\title{
DOI 10.15407/mics2020.10.093
}

\section{УДК 94:330.34 (430) «XIV/XV»}

\section{Анна Руднічук,}

аспірантка кафедри історї стародавнього світу та середніх віків Київського національного університету імені Тараса Шевченка

\author{
anna-rud@ukr.net
}

https://orcid.org/0000-0002-6835-6201

\section{АУСБЮРГЕРИ ТА ПФАЛЬБЮРГЕРИ У НІМЕЦЬКИХ МІСТАХ XIV-XV СТ.}

До соичільного складу німецьких міст доби Пізнього Середньовіччя входили не тільки громадян, щзо проживали безпосередньо на території бурга. Низка економічних, політичних і військових чинників зумовила потребу залучення міською владою як нових бюргерів населення із прилеглих до міста територій, а також осіб, шо не проживали в містах. У нормативно-правових актах иентральної влади та міст вони позначені як «пфальбюргери» та «аусбюргери». Першу категорію населення представляли в основному знать $і$ вищий клір, а другу - селяни та нижчі верстви населення пізньосередньовічної Німеччини.

У статті проаналізовано основні тенденції розвитку циих двох соиіальних категорій німецььких міст XIV-XV cm., їх термінологічне визначення в історіографії, відображення у джерелах, суперечливі моменти стосовно подвійного позначення обох термінів, статус та правове врегулювання, як зі сторони міста, так $i$ боку иентральної влади, відмінності у їхніх відносинах із містами та чентральною владою, а також винятки шодо позначення циих понять у бюргерському середовищі різних міст. Значну увагу приділено аналізу ідентифікації аусбюрегрів і пфальбюргерів у межсах міського простору, на загальнодержавному рівні, причини їх прийняття до середовиша бюргерського населення, основні переваги і недоліки, шо приносили для міста иі громадяни. Розглянуто процеси врегулювання сплати податків аусбюргерами та пфальбюргерами, фінансові виплати, які могли надавати міста для иих сочіальних промарків. Проаналізовано причини ліквідації циих категоріи 
${ }^{1}$ Стоклицкая-Терешкович, В. (Сост.) (1936). Договор между городом Страсбургом и страсбургским епископом, 1368 г. В Немецкий город $X I V-X V$ вв. (с. 152-153). Москва: Государственное социально-экономическое издательство.

${ }^{2}$ Lünig, von J. (1713). Die Hoch-Teutsche Ubersetzung der Güldenen Bull Kaysers Carl des Vierten, 1356, In Das Teutsche Reichs-Archiv (Bd. 1, S. 34-53). Leipzig: Friedrich Lanckische Erben Verlag.

${ }^{3}$ Schwalm, J. (Ed.). (1906). Constitutio pacis generalis ad Rhenum superiorem. 19 Aug. 1310 In Constitutiones Et Acta Publica Imperatorum Et Regum (pp. 355-358). Hannoverae, Impensis Bibliopolii Hahniani, Tomus 4.

${ }^{4}$ Schmoller, von G. (1875). Strassburg zur Zeit der Zunftkämpfe und die Reform seiner Verfassung und Verwaltung im XV. Jahrhundert: Rede gehalten zur Feier des Stiftungsfestes der Universität Strassburg am 1. Mai 1875. Strassburg, Trübner.

${ }^{5}$ Asmus, B. (1987). Die Bevölkerung: Entwicklung und Sozialstruktur. In D. von Denecke, \& H.-M.

Kühn (Eds.). Göttingen: Von den Anfängen bis zum Ende des Dreissigjährigen Krieges (Bd. 1, S. 161199). Göttingen: Vandenhoeck und Ruprech.

${ }^{6}$ Hesse, P. (2012). Nachrichten aus Köln. Studien zu den Briefen des städtischen Rats zur Zeit des Neusser Krieges, Inaugural-Dissertation zur Erlangung des Doktorgrades an der Philosophischen Fakultät der Universität zu Köln. Universität zu Köln, Köln. населення пізньосередньовічного німецького міста, конфронтації, щзо виникали між радами міст і знаттю стосовно наявності таких сочіальних прошарків, можливості подальшого розв'язання конфліктів, а також постанови про ліквідацію циих категорій населення, умови їх переходу до статусу повноправних бюргерів.

Ключові слова: пізньосередньовічне німецьке місто, аусбюргери, пфальбюргери, сочіальний розвиток.

$\Pi$ роблематика вивчення соціального становища аусбюргерів і пфальбюргерів у пізньосередньовічному німецькому місті є актуальною в сучасній медієвістичній науці. Як аусбюргери, так і пфальбюргери проживали поза межами міста, формально залишаючись у тому статусі, в якому перебували до прийняття громадянства. Таке становище призводило до нестабільних відносин міста та центральної влади, що часто спричиняло ліквідацію в місті цих категорій населення. Важливим залишається вивчення причин появи таких верств населення, створення їх альтернативних варіантів у випадку заборон із боку центральної влади приймати аусбюргерів чи пфальбюргерів як громадян міста, а також аналіз системи їх оподаткування.

Джерельна база цієї теми є доволі обширною. Варто згадати документи, вміщені у збірці 1936 р. «Німецьке місто XIV-XV ст.» (переклад і коментарі - радянської дослідниці В. Стокліцької-Терешкович), зокрема «Угоду між містом Страсбургом та страсбурзьким єпископом 1368 р.», що регламентувала основні взаємовідносини між аусбюргерами та містом і єпископом, основні повинності та сплату податків ${ }^{1}$. Золота Булла Карла IV від 1356 р., вміщена у однойменній збірці документів Німецького Імперського Архіву за редакцією Й. К. Люніга, передбачала заборону приймати пфальбюргерів як громадян міст Німеччини ${ }^{2}$. Іншим важливим документом є «Постанова про найвищий загальний Рейнський мир» від 19 серпня 1310 р., вміщена у збірці документів «Офіційні постанови та акти імператорів та князів», опублікованій 1906 р. за редакцією Й. Швальма ${ }^{3}$ Вона містить інформацію про умови отримання пфальбюргерами громадянства у містах під час ліквідації цього інституту.

Дослідженням розглядуваної проблематики займалися як вітчизняні, так і зарубіжні автори. Німецька історіографія представлена такими дослідниками, як Г. фон Шмоллер, Б. Асмус, П. Бліклє, П. Гессе, та Е. Ізенманн. У праці Г. фон Шмоллера «Страсбург під час боротьби гільдій та реформи його конституції та управління у XV ст.», що вийшла 1875 р., автор аналізує відмінності у соціальному становищі аусбюргерів і пфальбюргерів, а також дає їх категоріальне визначення ${ }^{4}$. Б. Асмус, досліджуючи наприкінці XX ст. соціальний розвиток середньовічного Геттінгена, наголошувала на особливому складі населення, що входило до прошарку аусбюргерів і дещо відрізнялося від загальноприйнятого в усіх інших містах 5 . Тематики розвитку інститутів «аусбюргерства» у м. Кельн торкається П. Гессе у своїй дисертації «Відомості із Кельна. Дослідження листів міської ради в часи Нойсської війни», яка вийшла у 2012 р. ${ }^{6}$ Автор розглядає конфлікти міста із місцевим єпископом, а 
${ }^{7}$ Isenmann, E. (2014). Die deutsche Stadt im Mittelalter 1150-1550: Stadtgestalt, Recht, Verfassung, Stadtregiment, Kirche, Gesellschaft, Wirtschaft. 2te Auflage. Köln: Böhlau Verlag.

${ }^{8}$ Scott, T. (2007). The City-State in the Germanspeaking Lands. In Ch. Ocker, M. Printy, P. Starenko, \& P. Wallace (Eds.), Politics and Reformations: Communities, Polities, Nations, and Empires (pp. 3-66). Leiden, Boston: BRILL.

${ }^{9}$ Scott, T. (2001). Town and country in Germany, 1350-1600. In S. R. Epstein (Ed.), Town and Country in Europe, 1300-1800 (pp. 202-229). Cambridge: Cambridge University Press.

${ }^{10}$ Дятлов, В. (2007). «Хаусгеноссен» в немецких городах XV-XVI вв. Вестник Удмуртского университета. Серия «История и филология», 7, 108-122.

${ }^{11}$ Witte, von H., \& Wolfram, G. (1896). Bischof Friedrieh sehließt mit der Stadt der Äusbürger weigen einen fünfjährigen Vergleich. 1377 Februar 6. In Urkundenbuch der Stadt Strassburg. Politische Urkunden von 1365 bis 1380 (Bd. 5, 2-te Hälfte, S. 930). Straßburg: Verlag von K. Trübner. також заходи, яких воно вживало з метою залучення німецьких князів із прилеглих територій для підтримки у конфронтації із кліром. Сучасний німецький дослідник Е. Ізенман у праці «Німецьке місто в середньовіччі (1150-1550рр.): устрій міста, закон, конституція, міське ополчення, церква, суспільство, економіка», друга редакція якої побачила світ у 2014 р., підкреслює відмінність між аусбюргерами та пфальбюргерами, досліджує їхній соціальний статус, а також переваги і недоліки, які ці категорії населення могли принести для пізньосередньовічного німецького міста ${ }^{7}$ Серед англійської історіографії варто виділити роботи Т. Скотта «Місто-держава в німецькомовних країнах» i «Місто та держава в Німеччині у 1350-1600 pp.»9, де автор аналізує причини та альтернативні шляхи розв'язання проблеми заборон пфальбюргерів у пізньосередньовічних німецьких містах. Поміж праць українських авторів згадаємо статтю відомого медієвіста В. Дятлова “"Хаусгеноссен” у німецьких містах XV-XVI ст.» ${ }^{10}$, де історик дає пояснення терміна «пфальбюргери» у контексті переходу маргінальних верств населення без власного житла до цієї категорії міських жителів.

Хронологічні межі статті охоплюють XIV-XV ст. У цей період відбулися зміни у соціальному становищі пфальбюргерів та аусбюргерів, а саме спроби ліквідації цих станів, пошуки альтернативних інституцій.

Метою цієї статті є розкриття на основі джерел та спеціальної історичної літератури основних аспектів соціального розвитку пфальбюргерів та аусбюргерів у пізньосередньовічному німецькому місті.

Соціальний статус аусбюргерів і пфальбюргерів у німецьких містах пізнього Середньовіччя пов’язаний із їх позначенням у джерелах та історіографії. У нормативно-правових актах, що стосуються німецьких міст XIV-XV ст., аусбюргери в основному згадані як «uzburgere» ${ }^{11}$ aбо «uz burgere» ${ }^{12}$. Пфальбюргери позначені в офіційних документаціях міст Німеччини як «pfalburgere» ${ }^{13}$ або «phalburgere» ${ }^{14}$. Нормативно-правові акти XIV-XV ст. свідчать про них як «про громадян, що їх зазвичай називають пфальбюргерами» («civibus, qui pfalburger dicuntur vulgariter») ${ }^{15}$. Таке форму-

${ }^{12}$ Historische Comission Bei der Könige Akademie der Wissenschaften. (1865). Zweiter Zunftbrief. 1368, Dec. 16. Die Augsburger

Chronik von 1368 bis 1406 mit Fortsetzung bis 1447. In Die Chroniken der Schwäbischen Städte. Augsburg, Hrsg. durch die Historische

Comission Bei der Könige Akademie der Wissenschaften (Bd. 1, S. 145). Leipzig: Verlag von G. Hirzel.

${ }^{13}$ Schwalm, von J. (1906). Epistola de coronatione medolanensi et pace generali. 1311 Januar 7. In Constitutiones Et Acta Publica Imperatorum Et Regum (p. 480). Hannoverae: Impensis Bibliopolii Hahniani, Tomus 4.

${ }^{14}$ Witte, von H., \& Wolfram, G. (1896). Kaiser Karl IV gebietet der Stadt Straßburg, ihre Pfahlbürger abzuthun. 1372 October 7. In Urkundenbuch der Stadt Strassburg. Politische Urkunden von 1365 bis 1380 (Bd. 5, 2-te Hälfte, S. 802). Straßburg: Verlag von K. Trübner.

${ }^{15}$ Schwalm, von J. Epistola de coronatione medolanensi, 480. 
${ }^{16}$ Böhmer, von J. F. (1836). Städtetag zu Worms. 1254 Oct. 6. In Codex diplomaticus Moenofrancofurtanus. Urkundenbuch der Reichsstadt Frankfurt (1 T., S. 105). Frankfurt am Main, Franz Varrentrapp,

${ }^{17}$ Witte, von H., \& Wolfram, G. Kaiser Karl IV, 803.

${ }^{18}$ Ibid., 803.

${ }^{19}$ Lünig, von J. Die Hoch-Teutsche Ubersetzung, 45

${ }^{20}$ Стоклицкая-Терешкович, В. Договор между городом Страсбургом, 152.

${ }^{21}$ Там же.

${ }^{22}$ Там же, 153

${ }^{23}$ Schmoller, von G. Strassburg zur Zeit der Zunftkämpfe, 34. лювання корелюється із більш раннім позначенням у латиномовних джерелах ХІІІ ст., де німецьких бюргерів із заміських територій називали «неосілими громадянами», тобто «cives non residentes, quod vulgo appellatur paleburger» ${ }^{16}$, що свідчить про наявність як офіційного, так і часто вживаного позначення для цієї категорії населення. Обидва терміни у документах іноді вживають одночасно щодо однієї й тієї самої категорії населення. Приміром, у наказі Карла IV до м. Страсбург від 7 жовтня 1372 р., де йдеться про вимогу припинити приймати пфальбюргерів як своїх громадян, ці поняття є тотожними: «...аусбюргери, яких називають пфальбюргерами» («...soliche auzburger, die man nennet phalburger») ${ }^{17}$. При цьому правитель окреслює осіб, яких має на увазі: «Ми дізналися.. що князі, рицарі та кнехти не хочуть дотримуватися миру... в Ельзасі через... людей, яких ви відняли та прийняли і маєте в якості своїх бюргерів» ${ }^{18}$.

Постанови та нормативні акти рідко надають конкретні визначення стосовно цих двох категорій. Зокрема, у виданій 1356 р. Золотій Буллі пфальбюргери характеризуються як «громадяни та піддані», які «прагнуть скинути з себе пута... підданства... знайти житло в інших містах та стати громадянами там, проте, насправді продовжують проживати на землях їх колишніх господарів.. претендуючи (водночас) на користування вольностями і захистом тих міських громад, до яких вони так переходять...» ${ }^{19}$.

Щодо аусбюргерів ідентифікація у нормативних актах відбувається не зовсім чітко. Укладена 1368 р. угода між містом Страсбург та єпископом Іоанном III щодо аусбюргерів виділяє серед них знатних осіб окремим положенням: «...ті аусбюргери Страсбурга, які належать до знаті, і які переселилися в наші володіння та осіли там, повинні бути звільнені від “Bede”»" у цьому джерелі згадуються як люди, «які живуть серед нас у всіх наших містах, селах і володіннях» ${ }^{21}$. Хоча $€$ й одне твердження, що натякає на їх належність до знаті, коли в угоді йдеться про слуг осілих міських жителів, які мешкають «у володіннях та дворах» аусбюргерів 22.

Наприкінці XIX ст. німецький економіст та історик Г. фон Шмоллер щодо міста Страсбурга пфальбюргерами називав міських жителів і селян, які проживають за межами міста. Аусбюргерів, на думку дослідника, представляла знать, що не мешкала в містах, але перебувала у ленних або службових зв'язках із прилеглими до міста територіями ${ }^{23}$.

Сучасний німецький історик Е. Ізенман дещо розширює ці поняття. Обидва терміни не мають чіткого розрізнення в постановах та нормативних актах, тому часто здаються взаємозамінними. До того ж термін «аусбюргер» має ширше значення і може охоплювати пфальбюргерів, тому іноді його використовували в міських джерелах для того, щоб уникнути негативного позначення пфальбюргерів щодо селян. Пфальбюргерами Е. Ізенман називає осіб, що мешкають на прилеглих територіях, набувають права, аналогічні громадянським, проте продовжують проживати за межами міста, на довколишніх землях. Вони сплачують податки у міську скарбницю, дають клятву місту, захищають 
${ }^{24}$ Isenmann, E. Die deutsche Stadt im Mittelalter, 149.

${ }^{25}$ Gothein, von E. (1892). Wirtschaftsgeschichte des Schwarzwaldes und der angrenzenden Landschaften. Strassburg, Verlag von Karl J. Trübner, Bd. 1. Städte- und Gewerbegeschichte, 175.

${ }^{26}$ Дятлов, В. «Хаусгеноссен» в немецких городах, 116

${ }^{27}$ Isenmann, E. Die Deutsche Stadt im Mittelalter, 150.

${ }^{28}$ Asmus, B. (1987). Die Bevölkerung, 184.

${ }^{29}$ Scott, T. The City-State, 59.

${ }^{30}$ Ibid., 60 .

${ }^{31}$ Blickle, P. (2000). Kommunalismus. Skizzen einer gesellschaftlichen Organisationsform:

Oberdeutschland. München: R. Oldenbourg Verlag, Bd. 1, 126. бюргерські права упродовж певного періоду, а також підпорядковуються міській юрисдикції. Щоб закріпитися у місті, вони можуть купувати там оподатковане майно та проживати певний час 24.

Походження терміна пов'язане з тим, що потенційні громадяни проживали в межах прилеглої місцевості, буквально на окраїнних територіях міста («an den Pfählen der Stadt») ${ }^{25}$. Український учений В. О. Дятлов позначає пфальбюргерів як своєрідних «посадських жителів» або «міщан» ${ }^{26}$. До аусбюргерів належать наділена землею знать, графи, лицарі, що мають будь-яку власність, знатні зброєносці та вільні особи, які отримали бюргерські права без обов'язкового осідання у місті, а також клірики, служителі духовних орденів та об'єднань ${ }^{27}$.

Деякі міста щодо термінологічного визначення «аусбюргерів» та «пфальбюргерів» могли становити винятки. Б. Асмус, вивчаючи ці категорії населення у м. Геттінгені, зауважила, що вони дещо відрізнялися від згаданих вище верств, які проживали в імперських містах. Дослідниця об'єднує два поняття та відносить до них учених, пасторів із прилеглих місцевостей, юристів, чиновників, що служили правителям довколишніх земель, а також синів місцевих бюргерів, які здобували освіту на інших територіях. Останні часто проживали на інших територіях, проте зберігали громадянство Геттінгена для того, щоб мати змогу отримати під час повернення батьківський будинок та вступити до місцевих гільдій. Причиною такої тенденції було те, що під час спадкування майна у Геттінгені немісцевим жителем останній повинен був стати громадянином міста упродовж року. Інакше він втрачав спадок або ж спадок обкладали високим податком ${ }^{28}$.

Концентрація, кількість, потреба міста в аусбюргерах і пфальбюргерах залежала в основному від територіальних та політичних особливостей. Зокрема, періодичні домовленості Кельна із рейнським дворянством протягом XIV-XV ст. можна розглядати як специфічну заміну неспроможності сформувати на прилеглих землях масштабні сільські поселення ${ }^{29}$.

На початку XV ст. деякі міста почали відмовлятися від пфальбюргерства на користь аусбюргерів: Аугсбург позбавився від селян, що проживали неподалік від міста, натомість надавав бюргерські права знаті. Останні залишалися бажаними громадянами для німецьких міст XIV-XV ст., тому що знать забезпечувала військовий і дипломатичний захист, зокрема доступ до замків. Інститут «пфальбюргерства» надавав тільки юридичну основу економічному проникненню міста до сільської місцевості. Проте цей аспект приносив міській адміністрації як додаткові прибутки, так і зобов'язання, які воно не завжди прагнуло виконувати ${ }^{30}$.

Отримання селянами фіктивного громадянства створювало незручності для князів та центральної влади, а також своєрідну невизначеність у їхньому соціальному становищі. Пфальбюргери залишалися селянами, бо продовжували займатися землеробством і мали феодала, але політично вони були міщанами, оскільки потрапляли під юрисдикцію міського законодавства, могли користуватися його захистом ${ }^{31}$. Це викликало невдоволення у багатьох князів. Приміром, єпископ Страсбурга Йо- 
32 Blickle, P. (2001). "Doppelpass” im Mittelalter. Ausbürger in oberdeutschen und schweizerischen Städten und der Verfall der feudalen Herrschaft. In H. von Bräuer, \& E. Schlenkrich, Die Stadt als Kommunikationsraum. Beiträge zur Stadtgeschichte vom Mittelalter bis ins 20. Jahrhundert (S. 44). Leipzig: Leipziger Universitätsverlag.

${ }^{33}$ Witte, von H., \& Wolfram, G. (1896) Bischof Lamprecht von Speyer an Straßburg. 6 Januar 1366. In Urkundenbuch der Stadt Strassburg. Politische Urkunden von 1365 bis 1380 (Bd. 5, 2-te Hälfte, S. 547). Straßburg, Verlag von K. Trübner.

${ }^{34}$ Blickle, P. (2001). “Doppelpass” im Mittelalter, 44

${ }^{35}$ Lünig, von J. Die Hoch-Teutsche Ubersetzung, 45 .

${ }^{36}$ Scott, T. Town and country in Germany, 208. ган фон Ліхтенберг скаржився 1356 р. на Рейхстазі у м. Мец, що багато селян переходять до фіктивного бюргерства, через що зменшується обсяг виконаних ними повинностей ${ }^{32}$.

Місто могло приймати до лав громадян селян, що проживали за його межами, не враховуючи інтересів центральної влади. Зокрема, шпеєрський єпископ Лампрехт фон Брунн у листі до ради та бургомістра Страсбурга 1366 р. скаржився стосовно включення нових громадян: «...пфальбюргери, яких ви на деякий час прийняли до себе, попри загальні заборони пана нашого імператора та кюрфюрстів, та... надалі плануєте у себе залишити, тому що вони не хочуть вас покидати... тих, які належать державі, ними вона володіє, прийняли без дозволу державного та завдали збитків» ${ }^{33}$.

Пфальбюргери стали причиною страху перед військовими заворушеннями. Зокрема, у 1431 p. імператор Сигізмунд висловлював занепокоєння стосовно того, що останні можуть спричинити конфлікти у Швабії ${ }^{34}$.

Офіційні закони про заборону перебування пфальбюргерів як громадян міста, прийняті німецькими правителями, набирали сили не одразу. Приміром, у Золотій Буллі 1356 р. Карл IV заборонив приймати пфальбюргерів до міст: «...відтепер і надалі згадані громадяни та піддані (пфальбюргери. - A. Р.) ...в жодному разі не повинні ні в яких землях, місцевостях і провінціях Священної імперії отримувати права і вольності тих міських громад... громадянства яких вони... домагаються... Якщо тільки вони, насправді, без обману, переселяються з усім своїм майном в ці міста... там проживають, приймаючи... на себе... міське право, податки, повинності... та інші подібні зобов'язання...»>

Хоча кількість громадян міста, що проживали за його межами, могло дещо зменшитися, однак вони не зникли зовсім. Зміни відбувалися залежно від ступеня підпорядкування територій центральній владі, а також доцільності самих інституцій. У Нюрнберзі, де були стійкі імперські зв'язки, продовжували дотримуватися букви офіційного закону та ліквідували ці верстви населення. В інших містах інститутам «пфальбюргерства», а пізніше й «аусбюргерства» вдалося трансформуватися. Приміром, у Франкфурті всі сільські жителі приміських територій офіційно переходили під судову юрисдикцію міста. Пізніше, у XV ст. зміни торкнулися й аусбюргерів: замість них було запроваджено низку повинностей та захисних об'єднань, зокрема можливості доступу до замків (т. зв. право відкриття, або Öffnungsrecht). Швабським містам вдалося зберегти обидва інститути. Хоча Ульм провадив подібну політику стосовно знаті доволі «дозовано», а згодом зовсім дистанціювався від неї. На території Ельзасу кількість бюргерів, що проживала за межами міст, навіть збільшиласяз ${ }^{36}$

Забороняючи пфальбюргерів, центральна влада надавала їм можливість стати повноцінними громадянами міста. У Земському мирі 19 серпня 1310 р. Генріх VII постановив для міст Страсбурга та Базеля: «Всі пфальбюргери повинні піти, а якщо вони хочуть стати бюргерами, то повинні безперервно перебувати (в місті. - A. Р.) зимою та влітку. Крайнім терміном... має бути день Святого 
${ }^{37}$ Schwalm, von J. Constitutio pacis generalis, 355 .

${ }^{38}$ Стоклицкая-Терешкович, В. Договор между городом Страсбургом, 152.

${ }^{39}$ Там же.

${ }^{40}$ Там же.

${ }^{41}$ Historische Comission Bei der Könige Akademie, 145.

${ }^{42}$ Стоклицкая-Терешкович, В. Договор между городом Страсбургом, 153.

${ }^{43}$ Hesse, P. Nachrichten aus Köln, 60.
Мартіна (11 листопада. - A. P.), щоб нам повідомити... чи вони бюргерами бажають стати, чи ні. I того, хто відмовиться, як було написано вище, жодне місто не повинно вважати бюргером» ${ }^{37}$.

Щодо оподаткування аусбюргерів, то воно складалося із грошових виплат та несення відповідних повинностей. Зокрема, у Страсбурзі основним податком для них вважався Bannbede, тобто податок для тих, хто проживає на лінії міста: «...аусбюргери зазначеного міста Страсбурга, живуть серед нас і в наших володіннях і мають там своє постійне місцеперебування, не повинні давати... в більшому розмірі, ніж раніше, податок, іменований “Bannbede"...»”8. До додаткових зобов'язань належали такі: «...брати участь у несенні вартової служби і прокладанні ровів разом з іншими нашими

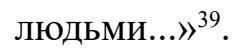

Своєрідну вигоду від аусбюргерів для міста Страсбург надавала участь перших у можливих союзах: «Вони повинні брати участь у всіх союзах, які утворюються в наших містах, селах і володіннях... також пропорційно своїй чисельності брати участь при укладенні цих союзів» ${ }^{40}$.

Податки іноді могли бути фіксованими, залежно від стану, до якого належав аусбюргер. Приміром, в Аугсбурзі, «якщо він $є$ аусбюргер із лицарського стану (helmsgenos), то повинен він пів року перебувати в місті та заплатити десять фунтів пфенінгів на будівництво.... $\rangle^{41}$.

Знатні громадяни міста, що проживали за його межами, входили у загальну судову юрисдикцію: «...Аусбюргерів Страсбурга судять ті самі суди, що й інших людей, які живуть у наших містах, селах і володіннях.... ${ }^{42}$.

Якщо аусбюргери були для міста важливими громадянами, то й воно зі свого боку могло здійснювати певні виплати. Зокрема, у 1418 р. м. Кельн мало розбіжності із місцевим архієпископом Дітріхом фон Моерсом. Бюргери уклали союз із герцогом Адольфом фон Бергом, який допомагав їм у боротьбі проти клірика. Сигізмунд I Люксембург, який на прохання єпископа наказав герцогу припинити відносини з містом, примусив шукати інших можливостей альянсу. Тому місто Кельн приймало до своїх лав як громадян представників знаті, роблячи їх аусбюргерами. Щоб краще закріпити подібних бюргерів на нових місцях, місто виплачувало щорічну ренту, яку не можна було позичати, закладати або продавати, а ії розмір залежав від кількості наданих у розпорядження міста контингенту. До ренти також належала й додаткова оплата, що зазвичай сягала декілька сотень гульденів. Якщо одна зі сторін хотіла розірвати угоду, то мала повернути назад ці виплати. У цьому випадку сума була доволі обтяжливою для аусбюргерів, тому слугувала неабияким фактором продовження відносин із Кельном. Ще одним способом закріпити знатного громадянина було орендування житла за рахунок міста на момент перебування там аусбюргера ${ }^{43}$. Ці заходи сприяли кращому зв'язку міста та знаті.

Отже, соціальний розвиток аусбюрегрів і пфальбюргерів у пізньосередньовічному німецькому місті відбувався нерівномірно, а їх поява у бюргерському середовищі залежала в основному від 
потреби міста сформувати зону економічного впливу або військового захисту на прилеглих територіях. Аналіз джерел та історіографії показав, що ці два поняття є доволі варіативними. Умовно можна віднести аусбюргерів до середовища знаті та вищого кліру, а пфальбюргерів - до селян і нижчих верств населення Німеччини. Виняток могли становити такі міста, як Геттінген, позаміськими бюргерами у яких були викладачі університетів, діти бюргерів, що проходили навчання на інших територіях, і священники. Реалізація постанов стосовно ліквідації аусбюргерів і пфальбюргерів залежала від ступеня зв'язку міста із центральною владою та відбувалася нерівномірно, іноді з пошуками альтернативних інституцій. У таких імперських містах, як Нюрнберг, ліквідація відбувалася інтенсивніше. Натомість інші міста, подібно до Швабії, продовжували приймати до громадянського середовища аусбюргерів і пфальбюргерів або шукати альтернативні замінники. Оподаткування цих категорій населення передбачало фінансові виплати, а у випадку аусбюргерів також несення військової повинності, вступ до міських союзів і надання власного замку у разі військових конфліктів.

Перспективи подальших досліджень із проблематики розвитку інституцій «пфальбюргерства» та «аусбюргерства» в німецьких містах XIV-XV ст. залишаються відкритими. Зокрема, варто приділити увагу системі оподаткування громадян міст із сільських територій, кількісному складу обох категорій позаміського бюргерства. Також ця тематика потребує докладнішого аналізу подібних верств населення у контексті порівняння регіональних особливостей у межах Німеччини.

\section{References}

Asmus, B. (1987). Die Bevölkerung: Entwicklung und Sozialstruktur, Göttingen: Von den Anfängen bis zum Ende des Dreissigjährigen Krieges. In D. Denecke, H.-M. Kühn (Eds.). Göttingen: Von den Anfängen bis zum Ende des Dreissigjährigen Krieges (Bd. 1, S. 161-199). Göttingen: Vandenhoeck \& Ruprech.

Blickle, P. (2000). Kommunalismus. Skizzen einer gesellschaftlichen Organisationsform: Oberdeutschland. München: R. Oldenbourg Verlag.

Blickle, P. (2001). "Doppelpass" im Mittelalter. Ausbürger in oberdeutschen und schweizerischen Städten und der Verfall der feudalen Herrschaft'. In H. Bräuer, \& E. Schlenkrich (Eds.), Die Stadt als Kommunikationsraum. Beiträge zur Stadtgeschichte vom Mittelalter bis ins 20. Jahrhundert (S. 37-48). Leipzig: Leipziger Universitätsverlag.

Böhmer, J. F. (1836). Städtetag zu Worms. 1254 Oct. 6. In Codex diplomaticus Moenofrancofurtanus. Urkundenbuch der Reichsstadt Frankfurt (1. Teil., S. 104-106). Frankfurt am Main: Franz Varrentrapp.

Dyatlov, V. (2007). "Hausgenossen" v nemetskikh gorodakh XV-XVI vv. Vestnik Udmurtskogo universiteta. Seriya Istoriya i filologiya, 7, 108-122.

Gothein, E. (1892). Wirtschaftsgeschichte des Schwarzwaldes und der angrenzenden Landschaften. Strassburg: Verlag von Karl J. Trübner. 
Hesse, P. (2012). Nachrichten aus Köln. Studien zu den Briefen des städtischen Rats zur Zeit des Neusser Krieges. Inaugural-Dissertation zur Erlangung des Doktorgrades an der Philosophischen Fakultät der Universität zu Köln. Universität zu Köln, Köln.

Historische Comission Bei der Könige Akademie der Wissenschaften. (1865). Zweiter Zunftbrief. 1368, Dec. 16. Die Augsburger Chronik von 1368 bis 1406 mit Fortsetzung bis 1447. In Die Chroniken der schwäbischen Städte. Augsburg (Bd. 1, S. 135-149). Leipzig: Verlag von G. Hirzel.

Isenmann, E. (2014). Die deutsche Stadt im Mittelalter 1150-1550: Stadtgestalt, Recht, Verfassung, Stadtregiment, Kirche, Gesellschaft, Wirtschaft. Köln: Böhlau Verlag.

Lünig, von J. (1713). Die Hoch-Teutsche Ubersetzung der güldenen Bull Kaysers Carl des Vierten. In Das Teutsche Reichs-Archiv (Bd. 1, S. 34-53). Leipzig: F. Lanckische Erben Verlag.

Schmoller, von G. (1875). Strassburg zur Zeit der Zunftkämpfe und die Reform seiner Verfassung und Verwaltung im XV. Jahrhundert: Rede gehalten zur Feier des Stiftungsfestes der Universität Strassburg am 1. Mai 1875 Strassburg Trübner, Strassburg: Trübner.

Schwalm J. (1906). Constitutio pacis generalis ad Rhenum superiorem. 19 Aug. 1310. In Constitutiones Et Acta Publica Imperatorum Et Regum (pp. 355-358). Hannoverae: Impensis Bibliopolii Hahniani, Tomus 4.

Schwalm J. (1906). Epistola de coronatione medolanensi et pace generali. 1311 Januar 7. Constitutiones Et Acta Publica Imperatorum Et Regum. In Constitutiones Et Acta Publica Imperatorum Et Regum (pp. 49-480). Hannoverae: Impensis Bibliopolii Hahniani.

Scott, T. (2001). Town and country in Germany, 1350-1600. In S. R. Epstein (Ed.), Town and Country in Europe, 1300-1800 (pp. 202-229). Cambridge: Cambridge University Press.

Scott, T. (2007). The City-State in the German-speaking Lands. In Ch. Ocker, M. Printy, P. Wallace, \& P. Starenko (Eds.), Politics and Reformations: Communities, Polities, Nations, and Empires (pp. 3-66). Leiden, Boston: BRILL.

Stoklitskaya-Tereshkovich, V. (1936). Dogovor mezhdu gorodom Strasburgom i strasburgskim yepiskopom, 1368 g. In Nemetskiy gorod XIV-XV vv. (pp. 152-153). Moskva: Gosudarstvennoye sotsial'no-ekonomicheskoye izdatel'stvo.

Witte H., \& Wolfram G. (1896). Bischof Friedrieh sehließt mit der Stadt der Äusbürger weigen einen fünfjährigen Vergleich. 1377 Februar 6. In Urkundenbuch der Stadt Strassburg. Politische Urkunden von 1365 bis 1380 (Bd. 5, 2-te Hälfte, S. 930-931). Straßburg: Verlag von K. Trübner

Witte H., \& Wolfram G. (1896). Bischof Friedrieh sehließt mit der Stadt der Äusbürger weigen einen fünfjährigen Vergleich. 1377 Februar 6. In Urkundenbuch der Stadt Strassburg. Politische Urkunden von 1365 bis 1380 (Bd. 5, 2-te Hälfte, S. 930-931). Straßburg: Verlag von K. Trübner.

Witte H., \& Wolfram G. (1896). Kaiser Karl IV gebietet der Stadt Straßburg, ihre Pfahlbürger abzuthun. 1372 October 7. In Urkundenbuch der Stadt Strassburg. Politische Urkunden von 1365 bis 1380 (Bd. 5, 2-te Hälfte, S. 802-803). Straßburg: Verlag von K. Trübner. 


\section{Anna Rudnichuk}

\section{OUTBURGHERS AND PALEBURGHERS IN GERMAN CITIES DURING THE XIV-XV CENTURIES}

The social composition of the German cities of the late Middle Ages included not only citizens living directly on the territory of the burg. A number of economic, political and military factors caused the requirement for the city authorities to attract as new burghers, people from the territories adjacent to the city, and people who do not live in cities. In the regulatory legal acts of the central government and cities, they are designated as "paleburghers" and "outburghers". The first category of such citizens was mainly represented by the noble people and upper clergy, and the second by the peasants and the lower strata of the society in the Late Medieval Germany.

This article researches the main development tendencies of these two social categories of German cities of the XIV$X V$ centuries, their terminological definition in historiography, representation in the sources, controversial points regarding the double designation of terms, social status and legal regulation, both from the side of the city, and from central authorities, differences in their relations with cities and central admnistration, as well as exceptions to the designation of these terms in the burgher environment of different cities. It also discusses the main processes for regulating the payment of taxes by outburghers and paleburghers, financial payments that could be provided by citie for these social groups. The author analyzes the reasons for the liquidation of these categories of the population in the late medieval German city, the confrontation that arose between city councils and the nobility about the existence of such groups of society, the possibility of further resolving these issues, as well as the conditions for their transition to the status of full-fledged burghers.

Keywords: Late Medieval city, outburghers, paleburghers, social development. 